\title{
Analisis Prioritas Pembangunan Subsektor Pertanian Tanaman Pangan Dalam Kaitannya Dengan Tingkat Kesejahteraan Petani Tanaman Pangan Di Tahun 2020 Sebagai Upaya Pemulihan Ekonomi Pada Masa Pandemi Covid-19
}

\author{
(Development Priority Analysis of Food Corps Agricultural Subsector in Relation with The Level \\ Of Food Corps Farmer Welfare In 2020 As Economic Recovery Effort During The Covid-19 \\ Pandemic)
}

Aryadi Solana

Badan Pusat Statistik Kabupaten Jembrana

Jalan Mayor Sugianyar No. 5, Kabupaten Jembrana, Bali

Email: aryadi.solana@bps.go.id

\begin{abstract}
ABSTRAK
Selama pandemi Covid-19, pertumbuhan ekonomi Indonesia mengalami kontraksi sebesar 2,07 persen di tahun 2020. Meskipun demikian, subsektor pertanian tanaman pangan tetap mampu tumbuh sebesar 3,54 persen. Akan tetapi, indikator Nilai Tukar Petani (NTP) tanaman pangan mengalami penurunan terbesar di tahun 2020 dibanding subsektor pertanian lainnya. Oleh karena itu, penelitian ini bertujuan melakukan analisis prioritas pembangunan subsektor pertanian tanaman pangan di Indonesia pada masa pandemi Covid-19 yang menggunakan kriteria penilaian dari analisis Location Quotient dan analisis Shift Share serta mengidentifikasi karakteristik tiap kelompok prioritas berdasarkan indikator pertumbuhan ekonomi, kontribusi subsektor pertanian tanaman pangan, dan indikator kesejahteraan petani. Hasil penelitian ini menunjukkan bahwa karkateristik kelompok Prioritas 1 memiliki potensi terbesar untuk menjadikan subsektor ini sebagai inisiator pemulihan ekonomi, yang kemudian dilanjutkan oleh kelompok Prioritas 2 hingga kelompok Alternatif. Akan tetapi, kelompok Prioritas 1 juga memiliki tantangan terbesar ditinjau dari karakteristik indikator kesejahteraan petani yang memiliki kinerja paling buruk akibat penurunan penerimaan petani tanaman pangan. Dengan demikian, untuk mengoptimalkan subsektor pertanian tanaman pangan sebagai inisiator pemulihan ekonomi, kebijakan pemerintah seharusnya tidak hanya berorientasi terhadap pengurangan biaya produksi petani, tetapi juga perlu mengutamakan kebijakan yang mendorong penyerapan produk-produk pertanian tanaman pangan untuk meningkatkan daya tawar produk yang dihasilkan petani tanaman pangan.
\end{abstract}

Kata kunci: pertanian tanaman pangan, pertumbuhan ekonomi, nilai tukar petani, prioritas

\begin{abstract}
The Covid-19 pandemic had an impact on Indonesia's economic growth, resulting in a contraction of 2.07 percent in 2020. Nevertheless, the food crops agricultural sub-sector was still able to grow by 3.54 percent. However, the Food Crops Farmer Term of Trade (FTT) indicator experienced the largest decline in 2020 compared to other agricultural sub-sectors. Therefore, this study aims to analyze the development priorities of the food crops agricultural sub-sector in Indonesia during the Covid-19 pandemic using assessment criteria from Location Quotient analysis and Shift Share analysis and to identify the characteristics of each priority group based on indicators of economic growth and the contribution of the food crop agricultural sub-sector, as well as indicators of farmers welfare. The results of this study indicate that the characteristics of the Priority 1 Group have the greatest potential to make this sub-sector the initiator of economic recovery, which is then continued by the Priority 2 Group to the Alternative Group. However, the Priority 1 Group also has the biggest challenges seen from the characteristics of farmers' welfare indicators that perform worst due to the decrease in the acceptance of food crop farmers. Thus, to optimize the food crops agricultural sub-sector as an initiator of economic recovery, government policies should not only be oriented towards reducing farmers production costs, but also need to prioritize policies that encourage the absorption of food crops agricultural products to increase the bargaining power of products produced by food crop farmers.
\end{abstract}

Keywords: agricultural food corps, economic growth, farmer term of trade, priorities

\section{PENDAHULUAN}

Pandemi Covid-19 telah menyebabkan resesi global yang parah dengan dampak yang berbeda-beda di berbagai negara (IMF, 2021). Dalam publikasi World Bank (2021), pertumbuhan ekonomi global terkontraksi sebesar 3,5 persen pada tahun 2020 akibat pandemi Covid-19. Sementara itu, pandemi Covid-19 memberi 
dampak terhadap peningkatan tingkat kemiskinan di Indonesia sebesar 0,97 persen secara year-on-year per September 2020 (BPS, 2021a). Memburuknya kinerja indikator kemiskinan ini sesuai dengan kinerja indikator pertumbuhan ekonomi yang ditunjukan dari laju pertumbuhan Produk Domestik Bruto (PDB). Pada tahun 2020, pertumbuhan ekonomi Indonesia mengalami kontraksi sebesar 2,07 persen secara cumulative-tocumulative (BPS, 2021b).

Jika dilihat dari pertumbuhan ekonomi masing-masing lapangan usaha di Indonesia, 10 dari 17 lapangan usaha mengalami kontraksi pertumbuhan ekonomi pada tahun 2020. Sementara 7 lapangan usaha dengan nilai Produk Domestik Bruto (PDB) yang masih mampu tumbuh positif di tahun 2020, antara lain pertanian, pengadaan air, informasi komunikasi, jasa keuangan, real estate, jasa pendidikan, jasa kesehatan, dan jasa lainnya (BPS, 2021b). Di antara 7 lapangan usaha tersebut, pertanian merupakan lapangan usaha yang memberi kontribusi terbesar terhadap perekonomian Indonesia di tahun 2020 yaitu sebesar 13,7 persen (BPS, 2021b).

Menurut hasil penelitian Alwandi dan Muchlisoh (2020), pemerintah Indonesia hendaknya melakukan pemulihan ekonomi diawali dari sektor pertanian. Hal ini disebabkan kondisi perekonomian di provinsiprovinsi yang memiliki sektor basis pertanian masih lebih baik dibandingkan provinsi-provinsi yang tidak memiliki sektor basis pertanian. Menurut Mellor (2017), pada negara-negara berpendapatan menengah ke bawah, adanya kontraksi pertumbuhan ekonomi di sektor pertanian akan memiliki dampak yang lebih besar dalam peningkatan kemiskinan dibanding kontraksi pertumbuhan ekonomi sektor lainnya. Sementara itu, menurut peneliti Center for Indonesian Policy Studies (CIPS), Octania, di harian The Jakarta Post (2020), pembebasan aliran rantai pasok produk-produk pertanian dari Pembatasan Sosial Skala Besar (PSBB) membantu sektor pertanian bertahan di masa pandemi Covid-19.

Menurut BPS (2021b), sektor pertanian merupakan sektor ekonomi yang terdiri dari beberapa subsektor, di antaranya pertanian tanaman pangan, pertanian hortikultura, perkebunan, peternakan, kehutanan, perikanan, dan jasa pertanian. Berdasarkan data yang dirilis BPS, subsektor pertanian tanaman pangan menjadi sumber pertumbuhan ekonomi tahunan utama dari sektor pertanian dengan nilai 0,09 persen. Nilai ini lebih besar dibanding nilai sumber pertumbuhan ekonomi yang dihasilkan subsektor pertanian lainnya. Kondisi ini menunjukkan bahwa subsektor pertanian tanaman pangan merupakan penggerak terbesar dari sektor pertanian terhadap pertumbuhan ekonomi Indonesia di tahun 2020.

Kondisi sektor pertanian tidak hanya dapat digambarkan dari laju pertumbuhan ekonomi sektornya, tetapi juga dapat digambarkan dari indikator-indikator ekonomi lainnya. Salah satu indikator ekonomi yang menggambakan kondisi sektor pertanian adalah Nilai Tukar Petani (NTP). NTP merupakan indikator yang digunakan untuk mengukur daya tukar dari produk pertanian terhadap biaya produksi dan barang/jasa yang dikonsumsi petani (BPS, 2021d). Dengan demikian, NTP dapat menjadi proxy dari indikator kesejahteraan petani.

Pada tahun 2020, NTP sektor pertanian mengalami penurunan sebesar 0,11 persen dibanding 2019 (BPS, 2021d). Salah satu penyebabnya adalah terdapat empat subsektor yang mengalami penurunan nilai NTP, di antaranya subsektor tanaman pangan, subsektor tanaman hortikultura, subsektor peternakan, dan subsektor perikanan. Di antara empat subsektor tersebut, subsektor tanaman pangan menjadi subsektor dengan penurunan nilai NTP terendah, yaitu sebesar $-3,6$ persen (BPS, 2021d). Kondisi ini menunjukkan bahwa terdapat potensi dan tantangan dalam mengoptimalkan sektor pertanian untuk memperbaiki taraf kesejahteraan masyarakat di masa pandemi Covid-19 melalui perbaikan kondisi subsektor pertanian tanaman pangan. Dengan membaiknya taraf kesejahteraan petani tanaman pangan diharapkan tingkat kemiskinan dapat menurun.

Untuk mengidentifikasi potensi dan tantangan subsektor tanaman pangan secara lebih mendalam, diperlukan pemetaan terhadap potensi dan tantangan subsektor tanaman pangan di masing-masing provinsi untuk menentukan prioritas pembangunan. Oleh karena itu, penelitian ini bertujuan melakukan analisis prioritas pembangunan subsektor pertanian tanaman pangan di Indonesia pada masa pandemi Covid-19 dan mengidentifikasi karakteristik tiap kelompok prioritas berdasarkan indikator pertumbuhan ekonomi dan kontribusi subsektor pertanian tanaman pangan, serta indikator kesejahteraan petani.

\section{METODE}

\section{Analisis Location Quotient (LQ)}

Analisis Location Quotient (LQ) merupakan suatu teknik yang bertujuan untuk menentukan sektor/subsektor unggulan sebagai basis perekonomian di suatu wilayah (Stimson, Stough dan Roberts, 2006; 
Sudarmono, 2006). Pendekatan yang digunakan untuk menentukan sektor/subsektor i di provinsi j menjadi basis atau non basis yaitu dengan cara menghitung perbandingan relatif antara kontribusi output sektor/subsektor i terhadap output total pada provinsi j dengan kontribusi output sektor/subsektor i terhadap output total pada level nasional (Stimson, Stough dan Roberts, 2006; Sudarmono, 2006). Berikut rumus penghitungan analisis LQ:

$$
\mathrm{LQ}=\frac{(\mathrm{Yij} / \mathrm{Yj})}{(\mathrm{Yin} / \mathrm{Yn})}
$$

dengan $\mathrm{Y}_{\mathrm{ij}}=$ output sektor/subsektor i di provinsi $\mathrm{j}, \mathrm{Y}_{\mathrm{j}}=$ output total provinsi $\mathrm{j}, \mathrm{Y}_{\mathrm{in}}=$ output sektor/subsektor $\mathrm{i}$ di level nasional, $\mathrm{Y}_{\mathrm{n}}=$ output total nasional.

Menurut Sudarmono (2006), terdapat tiga kriteria penilaian dari nilai LQ yang dihasilkan, yaitu:

(1) Jika $L Q>1$, berarti sektor/subsektor i merupakan basis perekonomian provinsi j

(2) Jika $L Q=1$, berarti sektor/subsektor i merupakan tidak dapat dikategorikan basis atau non basis perekonomian provinsi $\mathrm{j}$

(3) Jika LQ < 1, berarti sektor/subsektor i merupakan non basis perekonomian provinsi $\mathrm{j}$

\section{Analisis Shift Share}

Analisis Shift-Share merupakan suatu teknik yang dikembangkan tahun 1960-an untuk menggambarkan kinerja sektor-sektor ekonomi di suatu wilayah yang dibandingkan dengan kinerja perekonomian nasional (Soepono, 1993). Pendekatan klasik dari Model Shift-Share mengukur perubahan variabel ekonomi di suatu sektor/subsektor seperti pertumbuhan output, kesempatan kerja, atau nilai tambah (D), dengan mendokomposisi perubahan tersebut menjadi tiga komponen (Soepono, 1993; Stimson, Stough dan Roberts, 2006). Jika penggunaan model ini diterapkan di level provinsi, maka ketiga komponen tersebut yaitu:

a. National Share (N) merupakan komponen perubahan yang disebabkan oleh laju/tren variabel ekonomi tersebut secara menyeluruh di level nasional (tanpa mempertimbangkan sektor/subsektor tertentu)

b. Industrial Mix atau Proportional Shift (M) merupakan komponen perubahan yang disebabkan oleh laju/tren variabel ekonomi suatu sektor/subsektor di level nasional

c. Competitive Effect atau Regional Share atau Differential Shift (C) merupakan komponen perubahan yang disebabkan oleh laju/tren variabel ekonomi suatu sektor/subsektor di level provinsi

Jika model di atas diaplikasikan pada pertumbuhan output sektor/subsektor i di provinsi $\mathrm{j}\left(\mathrm{D}_{\mathrm{ij}}\right)$, maka berikut adalah persamaannya:

$D_{i j}=N_{i j}+M_{i j}+C_{i j}$ dengan:

$\mathrm{N}_{\mathrm{ij}}=\mathrm{Y}_{\mathrm{ij} \cdot \mathrm{r}} \mathrm{r}_{\mathrm{n}}$

$M_{i j}=Y_{i j} \cdot\left(r_{i n}-r_{n}\right)$

$C_{i j}=Y_{i j} \cdot\left(r_{i j}-r_{i n}\right)$

dimana $\mathrm{Y}_{\mathrm{ij}}=$ output sektor/subsektor i di provinsi $\mathrm{j}, \mathrm{r}_{\mathrm{n}}=$ laju pertumbuhan output di level nasional, $\mathrm{r}_{\mathrm{in}}=$ laju pertumbuhan output sektor/subsektor i di level nasional, dan $r_{i j}=$ laju pertumbuhan output sektor/subsektor i di provinsi j.

Menurut Soepono (1993), terdapat empat kriteria penilaian yang dihasilkan dari pendekatan klasik Model Shift Share, yaitu:

(1)Jika $\mathrm{M}_{\mathrm{ij}}>0$, menunjukkan output sektor/subsektor i tumbuh lebih cepat dibanding output total pada level nasional

(perubahan output sektor/subsektor i menunjukkan kinerja yang lebih baik dibanding perubahan output total di level nasional)

(2) Jika $M_{\mathrm{ij}}<0$, menunjukkan output sektor/subsektor i tumbuh lebih lambat dibanding output total pada level nasional

(perubahan output sektor/subsektor i menunjukkan kinerja yang kurang baik dibanding perubahan output total di level nasional)

(3) Jika $\mathrm{C}_{\mathrm{ij}}>0$, menunjukkan output sektor/subsektor i pada provinsi j memiliki daya saing baik karena mampu tumbuh lebih cepat dibanding sektor/subsektor i pada level nasional

(perubahan output sektor/subsektor i pada provinsi j menunjukkan kinerja yang lebih baik dibanding perubahan output sektor/subsektor i pada level nasional)

(4) Jika $\mathrm{C}_{\mathrm{ij}}<0$, menunjukkan output sektor/subsektor i pada provinsi $\mathrm{j}$ tidak memiliki daya saing baik karena tumbuh lebih lambat dibanding sektor/subsektor i pada level nasional (perubahan output sektor/subsektor i pada provinsi j menunjukkan kinerja yang kurang baik dibanding perubahan output sektor/subsektor i pada level nasional). 


\section{Nilai Tukar Petani (NTP)}

Seperti yang sudah dijelaskan di atas, NTP dapat menjadi proxy dari indikator kesejahteraan petani. Ketika nilai NTP > 100 menunjukkan petani mengalami surplus, pendapatan petani naik lebih besar dibanding pengeluarannya. Sebaliknya, ketika nilai NTP $<100$ menunjukkan petani mengalami defisit, pengeluaran petani naik lebih besar dibanding pendapatannya (BPS, 2021d). Formula penghitungan NTP yaitu:

$\mathrm{NTP}=\mathrm{I}_{\mathrm{t}} / \mathrm{I}_{\mathrm{b}}$

dengan $\mathrm{I}_{\mathrm{t}}$ adalah indeks harga yang diterima petani dan $\mathrm{I}_{\mathrm{b}}$ adalah indeks harga yang dibayarkan petani.

\section{Konsep Pemikiran Penentuan Prioritas Pembangunan dan Analisisnya}

Dalam menentukan provinsi prioritas pembangunan untuk subsektor pertanian tanaman pangan, peneliti melakukan pengelompokan terhadap 34 provinsi menggunakan hasil dari analisis Location Quotient dan analisis Shift Share. Konsep pemikiran yang digunakan oleh peneliti dalam penentuan prioritas pembangunan dan analisisnya ditunjukan pada gambar berikut:

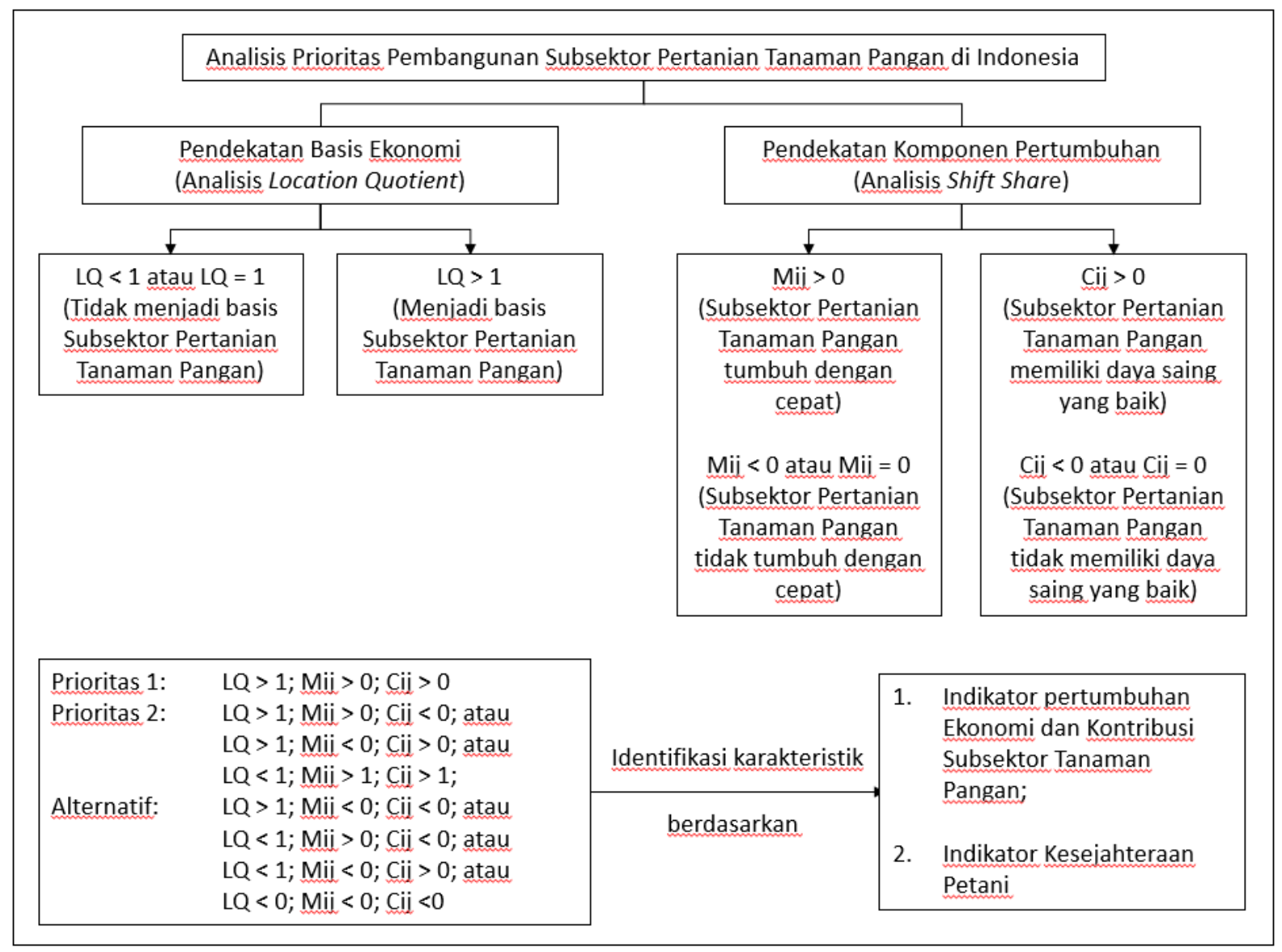

Gambar 1. Alur Pengelompokan Prioritas Pembangunan Subsektor Pertanian Tanaman Pangan.

Prioritas 1 merupakan kelompok provinsi-provinsi yang menjadi prioritas utama dalam pembangunan subsektor pertanian tanaman pangan. Kelompok ini memenuhi tiga kriteria penilaian yang digunakan. Kondisi ini menunjukkan bahwa subsektor pertanian tanaman pangan merupakan subsektor yang berperan besar terhadap perekonomian provinsi masing-masing, sehingga layak untuk dijadikan prioritas pembangunan subsektor pertanian tanaman pangan. Sementara itu, prioritas 2 merupakan kelompok yang memenuhi dua dari tiga kriteria penilaian. Provinsi-provinsi yang berada pada kelompok ini akan menjadi prioritas kedua setelah prioritas pertama dalam upaya pembangunan subsektor pertanian tanaman pangan. Sementara itu, kelompok aternatif merupakan provinsi-provinsi yang memenuhi kurang dari dua kriteria penilaian. Keberadaan kelompok ini tidak berarti bahwa provinsi yang tergabung di dalamnya dapat diabaikan dalam upaya pembangunan subsektor tanaman pangan. Akan tetapi, perlu dilakukan kajian lebih lanjut terhadap provinsiprovinsi tersebut terkait seberapa besar peran subsektor pertanian tanaman pangan dibandingkan sektor/subsektor lain dalam perekonomiannya untuk menjadi inisiator pemulihan ekonomi. Ketiga kelompok ini akan dianalisis secara deskriptif melalui indentifikasi karakteristik berdasarkan indikator pertumbuhan ekonomi dan kontribusi subsektor pertanian tanaman pangan, serta indikator kesejahteraan petani. 


\section{Tahapan Analisis}

Variabel yang digunakan pada penelitian ini antara lain:

1. PDB Indonesia Menurut Lapangan Usaha Tahun 2020 dan Laju Pertumbuhan PDB Menurut Lapangan Usaha Tahun 2020 yang bersumber dari Publikasi "Pendapatan Nasional Indonesia 2016-2020“ yang dirilis Badan Pusat Statistik;

2. PDRB Provinsi-Provinsi di Indonesia Menurut Lapangan Usaha dan Laju Pertumbuhan PDRB Provinsi-Provinsi di Indonesia Menurut Lapangan Usaha Tahun 2020 yang bersumber dari Publikasi "Produk Domestik Regional Bruto Provinsi-Provinsi di Indonesia Menurut Lapangan Usaha 2016-2020" yang dirilis Badan Pusat Statistik;

3. Indeks Harga yang Diterima Petani Tanaman Pangan, Indeks Harga yang Dibayar Petani Tanaman Pangan, dan Nilai Tukar Petani Tanaman Pangan Provinsi-Provinsi di Indonesia Tahun 2020 yang bersumber dari Publikasi "Statistik Nilai Tukar Petani 2020" yang dirilis Badan Pusat Statistik;

4. Produktivitas Padi dan Luas Lahan Padi Provinsi-Provinsi di Indonesia Tahun 2020 yang bersumber dari situs web Badan Pusat Statistik. dari:

Observasi pada penelitian ini adalah 34 provinsi di Indonesia. Tahapan analisis pada penelitian ini terdiri

1. Menghitung Nilai Location Quotient Subsektor Tanaman Pangan Provinsi-Provinsi di Indonesia Tahun 2020

2. Menghitung Nilai Komponen Industrial Mix dan Competitive Effect Subsektor Tanaman Pangan Provinsi-Provinsi di Indonesia Tahun 2020

3. Mengelompokkan masing-masing provinsi ke dalam tiga kelompok yaitu kelompok Prioritas 1, Prioritas 2, dan Alternatif berdasarkan nilai Location Quotient, Komponen Industrial Mix, dan Komponen Competitive Effect Subsektor Tanaman Pangan provinsi tersebut

4. Mengidentifikasi karakteristik tiap kelompok berdasarkan indikator pertumbuhan ekonomi dan kontribusi subsektor pertanian tanaman pangan, serta indikator kesejahteraan petani.

5. Interpretasi Hasil dan Pembahasan.

\section{HASIL DAN PEMBAHASAN}

\section{Prioritas Pembangunan Subsektor Pertanian Tanaman Pangan di Indonesia}

Berdasarkan hasil penghitungan Location Quotient, Komponen Industrial Mix, dan Komponen Competitive Effect, telah dilakukan pengelompokan terhadap 34 provinsi di Indonesia untuk menentukan prioritas pembangunan subsektor pertanian tanaman pangan. Hasil dari pengelompokan dapat terlihat pada Tabel 1.

Tabel 1. Hasil Pengelompokan Prioritas Pembangunan Subsektor Pertanian Tanaman Pangan di Indonesia Tahun 2020.

\begin{tabular}{ccc}
\hline Kelompok & Provinsi & Jumlah \\
\hline$(1)$ & $(2)$ & $(3)$ \\
\hline Prioritas 1 & Lampung, Jawa Barat, Daerah Istimewa Yogyakarta, Sulawesi Barat & 4 \\
& Aceh, Sumatara Utara, Sumatera Barat, Riau, Bengkulu, Kep. Bangka & \\
& Belitung, DKI Jakarta, Jawa Tengah, Jawa Timur, Banten, NTB, NTT, & \multirow{2}{*}{ Prioritas 2 } \\
& Kalimantan Barat, Kalimantan Selatan, Kalimantan Timur, Kalimantan & \\
& Utara, Sulawesi Utara, Sulawesi Tengah, Sulawesi Selatan, Gorontalo, & \\
Alternatif & Maluku & 9 \\
& Jambi, Sumatera Selatan, Kepulauan Riau, Bali, Kalimantan Tengah, & 9 \\
\hline
\end{tabular}

Sumber: Hasil olahan peneliti

Terlihat pada Tabel 1, sebanyak empat provinsi tergolong sebagai Prioritas 1 pembangunan subsektor pertanian tanaman pangan. Jumlah provinsi yang tergolong sebagai Prioritas 1, masih jauh lebih sedikit dibanding jumlah provinsi yang tergolong sebagai Prioritas 2. Sebanyak 21 provinsi tergolong sebagai Prioritas 2. Sementara itu, provinsi lain yang tidak tergolong sebagai Prioritas 1 maupun Prioritas 2, digolongkan sebagai kelompok Alternatif dalam pembangunan subsektor pertanian tanaman pangan di Indonesia. Terdapat sebanyak sembilan provinsi yang tergolong sebagai kelompok Alternatif. 


\section{Karakteristik Kelompok Prioritas Pembangunan Subsektor Pertanian Tanaman Pangan di Indonesia}

Pengelompokan prioritas pembangunan Subsektor Pertanian Tanaman Pangan di Indonesia Tahun 2020 menghasilkan tiga kelompok, yaitu kelompok Prioritas 1, Priortas 2, dan Alternatif. Jika ditinjau berdasarkan karakteristik pertumbuhan ekonominya yang ada pada Tabel 2., terlihat bahwa rata-rata pertumbuhan PDRB di Tahun 2020 pada kelompok Prioritas 1 mengalami kontraksi terdalam. Sebaliknya, jika yang ditinjau terbatas pada rata-rata pertumbuhan PDRB subsektor pertanian tanaman pangan di tahun 2020, kelompok Prioritas 1 memiliki nilai rata-rata pertumbuhan yang tertinggi. Bahkan nilai rata-rata pertumbuhannya hampir dua kali lipat pada kelompok Prioritas 2.

Pertumbuhan subsektor pertanian tanaman pangan pada provinsi-provinsi di kelompok Prioritas 1 juga menghasilkan rata-rata sumber pertumbuhan ekonomi yang positif. Hal ini berarti pertumbuhan subsektor pertanian tanaman pangan di kelompok Prioritas 1 mampu menahan kontraksi pertumbuhan ekonomi yang terjadi. Kondisi-kondisi ini menunjukkan bahwa subsektor pertanian tanaman pangan pada provinsi-provinsi di kelompok Prioritas 1 memiliki peran yang besar terhadap perekonomian daerahnya.

Terlepas dari keunggulan-keunggulan yang disebutkan di atas, karakteristik ini juga dapat menunjukkan bahwa provinsi-provinsi pada kelompok Prioritas 1 memiliki ketergantungan yang lebih besar terhadap subsektor pertanian tanaman pangan dibandingkan provinsi-provinsi pada kelompok Prioritas 2 dan Alternatif. Hal tersebut juga dapat terlihat dari struktur perekonomiannya. Rata-rata kontribusi subsektor ini di kelompok Prioritas 1 mencapai 16,55 persen terhadap perekonomian. Kontribusi yang dihasilkan ini secara rata-rata lebih besar dibandingkan kontribusi yang dihasilkan pada kelompok Prioritas 2 dan kelompok Alternatif. Kedua sudut pandang yang timbul dari karakteristik pertumbuhan ekonomi dan kontribusi subsektor ini menunjukkan bahwa subsektor pertanian tanaman pangan pada provinsi-provinsi di kelompok Prioritas 1 memiliki potensi dan tantangan terbesar untuk menjadi solusi terhadap pemulihan ekonomi pada masa pandemi Covid-19.

Tabel 2. Karakteristik Kelompok Prioritas Pembangunan Subsektor Pertanian Tanaman Pangan di Indonesia Tahun 2020 berdasarkan Indikator Pertumbuhan Ekonomi dan Kontribusi Subsektor.

\begin{tabular}{ccccc}
\hline Kelompok & $\begin{array}{c}\text { Rata-rata } \\
\text { Pertumbuhan PDRB } \\
\text { Tahun 2020 }(\%)\end{array}$ & $\begin{array}{c}\text { Rata-rata } \\
\text { Pertumbuhan PDRB } \\
\text { Subsektor Pertanian } \\
\text { Tanaman Pangan } \\
\text { Tahun 2020 }(\%)\end{array}$ & $\begin{array}{c}\text { Rata-rata Sumber } \\
\text { Pertumbuhan PDRB } \\
\text { Tahun 2020 }(\%)\end{array}$ & $\begin{array}{c}\text { Rata-rata Distribusi } \\
\text { PDRB Subsektor } \\
\text { Pertanian Tanaman } \\
\text { Pangan Tahun 2020 } \\
(\%)\end{array}$ \\
\hline Prioritas 1 & $(2)$ & $(3)$ & $(4)$ & $(5)$ \\
Prioritas 2 & $-2,31$ & 6,14 & 0,28 & 16,55 \\
Alternatif & $-1,15$ & 3,17 & $-0,06$ & 14,58 \\
\hline
\end{tabular}

Sumber: BPS, diolah

World Bank (2008) menjelaskan bahwa 86 persen orang di pedesaan bekerja di sektor pertanian. Dominannya sektor pertanian di pedesaan dapat menghasilkan fenomena re-urbanisasi di kalangan masyarakat perkotaan yang disebabkan mampunya sektor pertanian tumbuh positif di masa pandemi Covid-19. Dengan mampunya sektor pertanian untuk tumbuh positif, diharapkan sektor ini mampu menyerap tenaga kerja yang terdampak pandemi Covid-19.

Akan tetapi, penyerapan tenaga kerja di sektor pertanian tanpa diikuti dengan perbaikan taraf kesejahteraan petani tidak akan dapat menjadi solusi terhadap pemulihan ekonomi di masa pandemi Covid-19 ini. Seperti yang sudah dijabarkan di awal, Nilai Tukar Petani (NTP) Tanaman Pangan mengalami penurunan NTP terdalam di antara subsektor-subsektor dari sektor pertanian pada tahun 2020. Hal ini menunjukkan bahwa terjadi penurunan taraf kesejahteraan petani tanaman pangan pada tahun 2020.

Jika dilihat pada Tabel 3., provinsi-provinsi yang tergabung pada kelompok Prioritas 1 dan Prioritas 2 pembangunan subsektor pertanian tanaman pangan memiliki rata-rata NTP di bawah 100 pada tahun 2020. Hal tersebut menandakan petani tanaman pangan mengalami defisit di provinsi-provinsi ini akibat pengeluarannya lebih besar dibanding pendapatannya. Capaian ini berbanding terbalik dengan capaian indikator pertumbuhan ekonominya. Meskipun subsektor pertanian tanaman pangan mampu tumbuh positif di kelompok Prioritas 1 dan Prioritas 2, tetapi kondisi petani tanaman pangan pada kelompok tersebut masih mengalami defisit. 
Tabel 3. Karakteristik Kelompok Prioritas Pembangunan Subsektor Pertanian Tanaman Pangan di Indonesia Tahun 2020 berdasarkan Indikator Kesejahteraan Petani.

\begin{tabular}{cccc}
\hline Kelompok & $\begin{array}{c}\text { Rata-rata Nilai Indeks Harga } \\
\text { yang Diterima Petani } \\
\text { Tanaman Pangan (IT } \\
\text { Tahun 2020 }\end{array}$ & $\begin{array}{c}\text { Rata-rata Nilai Indeks Harga } \\
\text { yang Dibayar Petani } \\
\text { Tanaman Pangan (IB } \\
\text { Tahun 2020 }\end{array}$ & $\begin{array}{c}\text { Rata-rata Nilai Tukar Petani } \\
\text { Tanaman Pangan (NTP } \\
\text { Tahun 2020 }\end{array}$ \\
\hline Prioritas 1 & $(2)$ & $(3)$ & $(4)$ \\
\hline Prioritas 2 & 105,57 & 105,85 & 99,73 \\
Alternatif & 105,36 & 105,44 & 99,92 \\
\hline
\end{tabular}

Sumber: BPS, diolah

Jika ditelusuri lebih lanjut berdasar komponen penyusun NTP-nya, terlihat bahwa rata-rata pertumbuhan indeks harga yang diterima petani tanaman pangan (IT $\mathrm{TP}_{\mathrm{TP}}$ berada di bawah rata-rata pertumbuhan indeks harga yang dibayar petani tanaman pangan ( $\mathrm{IB}_{\mathrm{TP}}$ ) (lihat pada Tabel 4.). Bahkan untuk provinsi-provinsi yang tergolong sebagai Prioritas 1, perkembangan komponen $\mathrm{IT}_{\mathrm{TP}}$ mengalami rata-rata pertumbuhan yang negatif. Hal ini mengindikasikan terjadinya penurunan harga-harga produk pertanian tanaman pangan pada kelompok Prioritas 1. Di sisi lain, pertumbuhan output pertanian tanaman pangan pada kelompok Prioritas 1 mengalami pertumbuhan yang positif. Kondisi ini menunjukan terjadinya ekses penawaran (excess supply) dari produkproduk pertanian tanaman pangan yang diakibatkan tingkat penawaran produk pertanian tanaman pangan melebihi tingkat permintaannya, sehingga daya tawar produk pertanian tanaman pangan melemah hingga akhirnya nilai $\mathrm{IT}_{\mathrm{TP}}$ menurun. Dengan adanya kondisi tersebut, optimalisasi subsektor pertanian tanaman pangan untuk meningkatkan penyerapan tenaga kerja dan menggunakannya sebagai alternatif perbaikan kesejahteraan penduduk di masa pandemi Covid-19 berpotensi tidak mengalami keberhasilan.

Agar nilai $\mathrm{IT}_{\mathrm{TP}}$ pada kelompok Prioritas 1 mengalami pertumbuhan yang positif, bahkan mampu tumbuh lebih cepat dibanding nilai $\mathrm{IB}_{\mathrm{TP}}$, perlu adanya keseimbangan pasar (market equilibirum) baru pada kondisi harga yang lebih tinggi untuk produk-produk pertanian tanaman pangan. Untuk mewujudkan kondisi tersebut, maka perlu adanya peningkatan permintaan terhadap produk-produk pertanian tanaman pangan sehingga tingkat permintaannya melebihi tingkat penawarannya.

Tabel 4. Karakteristik Kelompok Prioritas Pembangunan Subsektor Pertanian Tanaman Pangan di Indonesia Tahun 2020 berdasarkan Perkembangan Indikator Kesejahteraan Petani.

\begin{tabular}{|c|c|c|c|}
\hline Kelompok & $\begin{array}{c}\text { Rata-rata Pertumbuhan per } \\
\text { Bulan IT } \mathrm{TT}_{\mathrm{TP}} \text { selama Tahun } \\
2020(\%) \\
\end{array}$ & $\begin{array}{c}\text { Rata-rata Pertumbuhan per } \\
\text { Bulan IB } \text { IP }_{\text {TP }} \text { selama Tahun } \\
2020(\%)\end{array}$ & $\begin{array}{c}\text { Rata-rata Pertumbuhan per } \\
\text { Bulan NTP } \\
2020(\%) \\
\end{array}$ \\
\hline (1) & $(2)$ & $(3)$ & $(4)$ \\
\hline Prioritas 1 & $-0,12$ & 0,21 & $-0,33$ \\
\hline Prioritas 2 & 0,04 & 0,21 & $-0,16$ \\
\hline Alternatif & 0,02 & 0,19 & $-0,17$ \\
\hline
\end{tabular}

Sumber: BPS, diolah

Dengan demikian, kebijakan-kebijakan pemerintah dalam meningkatkan kesejahteraan petani khususnya petani tanaman pangan seharusnya tidak hanya berorientasi terhadap pengurangan biaya produksi usaha pertanian tanaman pangan, seperti pemberian subsidi ataupun bantuan-bantuan pupuk maupun pestisida bagi petani. Kebijakan pemerintah mestinya juga berorientasi terhadap peningkatan permintaan produk-produk pertanian tanaman pangan dalam negeri melalui optimalisasi peran agro-industri dalam menyerap produkproduk pertanian tanaman pangan dalam negeri. Menurut Simatupang dan Isdijoso (1992), pembangunan agroindustri sebagai salah satu hilir produk pertanian juga perlu mendapat perhatian. Menurut hasil penelitiannya, lambatnya pembangunan agro-industri menjadi salah satu faktor menurunnya Nilai Tukar Sektor Pertanian. Kebijakan-kebijakan berupa pemberian stimulus-stimulus ekonomi terhadap Industri Pengolahan Hasil Pertanian (IPHP) Tanaman Pangan dapat mendorong kestabilan kondisi keuangan agroindustri tanaman pangan pada masa pandemi Covid-19. Tidak hanya itu, adanya stimulus-stimulus ekonomi dapat memunculkan agro-industri kreatif baru yang menjadi alternatif ekonomi bagi masyarakat di masa pandemi Covid-19. Selain upaya tersebut, mengoptimalisasi peran agro-industri juga dapat dimulai dengan melakukan pemetaan potensi-potensi produk tanaman pangan unggulan yang dimulai dari kelompok Prioritas 1, kemudian kelompok Prioitas 2, hingga terakhir kelompok Alternatif. Dengan adanya pemetaan ini, maka akan lebih 
mudah dalam melakukan perencanaan optimalisasi peran agro-industri dalam meningkatkan penyerapan produk pertanian tanaman pangan.

Meskipun demikian, berdasarkan rilis BPS (2021b) pada tahun 2020 tingkat konsumsi masyarakat mengalami penurunan yang disebabkan adanya pandemi Covid-19, sehingga kebijakan pemberian stimulusstimulus ekonomi untuk agro-industri hasil pertanian tanaman pangan tidak dapat secara instan memulihkan kondisi perekonomian. Akan tetapi, upaya-upaya ini dapat menjadi inisiator terhadap pemulihan kondisi perekonomian yang dapat terjadi secara bertahap.

\section{KESIMPULAN}

Berdasarkan hasil dan pembahasan di atas, disimpulkan bahwa 34 provinsi yang telah terbagi ke dalam tiga kelompok prioritas pembangunan memiliki karakteristik pertumbuhan ekonomi dan kesejahteraan petani tanaman pangan yang cukup berbeda. Jika subsektor pertanian tanaman pangan pada kelompok Alternatif secara rata-rata pertumbuhannya terkontraksi, sebaliknya subsektor ini secara rata-rata mampu tumbuh positif di provinsi-provinsi yang tergolong kelompok Prioritas 1 dan Prioritas 2. Akan tetapi pertumbuhan subsektor ini pada kelompok Prioritas 1 menunjukkan nilai sumber pertumbuhan yang positif, sedangkan pada kelompok Prioritas 2 menunjukkan nilai negatif. Hal ini berarti pertumbuhan subsektor pertanian tanaman pangan pada kelompok Prioritas 1 mampu menahan kontraksi pertumbuhan ekonomi yang terjadi. Kondisi ini menunjukkan subsektor pertanian tanaman pangan pada kelompok Prioritas 1 memiliki peran yang lebih besar dalam perkembangan ekonomi dibandingkan pada kelompok Prioritas 2 dan Alternatif. Hal ini tentunya menjadi potensi yang baik bagi provinsi-provinsi di kelompok Prioritas 1 untuk menjadikan subsektor pertanian tanaman pangan sebagai inisiator pemulihan ekonomi.

Di sisi lain, jika ditinjau dari karakteristik perkembangan indikator kesejahteraan petani yang ditunjukan oleh perkembangan nilai NTP tanaman pangan, kelompok Prioritas 1 menghadapi permasalahan yang lebih berat dibandingkan kelompok Prioritas 2 dan Alternatif. Secara rata-rata per bulannya, NTP tanaman pangan pada kelompok Prioritas 1 turun 0,33 persen. Penurunan ini jauh lebih besar dibandingkan penurunan nilai NTP tanaman pangan di kelompok Prioritas 2 dan Alternatif. Jika ditinjau dari komponen penyusunnya, penurunan ini disebabkan oleh penurunan indeks harga yang diterima petani secara rata-rata per bulannya, sedangkan indeks harga yang dibayar petani mengalami peningkatan secara rata-rata per bulannya. Kondisi hampir serupa juga terjadi pada kelompok Prioritas 2 dan Alternatif, dimana pertumbuhan indeks harga yang dibayar petani secara rata-rata per bulannya tumbuh melebihi pertumbuhan indeks harga yang dibayar petani. Kondisi ini menjadi tantangan bagi pemerintah untuk menerapkan kebijakan pertanian yang tidak hanya berorientasi terhadap penurunan biaya produksi, tetapi juga perlu mengutamakan kebijakan-kebijakan yang dapat meningkatkan permintaan produk-produk pertanian tanaman pangan dalam negeri melalui optimalisasi peran agro-industri dalam menyerap produk-produk pertanian tanaman pangan dalam negeri. Tidak hanya itu, pengoptimalan peran agro-industri juga dapat dimulai dengan adanya pemetaan potensi-potensi produk tanaman pangan unggulan yang dimulai dari kelompok Prioritas 1 yang kemudian dilanjutkan ke kelompok Prioritas 2, hingga terakhir kelompok Alternatif. Dengan demikian, perencanaan pengoptimalan peran agroindustri dalam menyerap produk pertanian tanaman pangan dalam negeri akan lebih mudah untuk dilakukan.

\section{DAFTAR PUSTAKA}

Alwandi, Mohammad Ammar dan Muchlisoh, Siti. (2020). Karakteristik Pertumbuhan Ekonomi dan Sektor Basis Provinsi di Indonesia pada Masa Pandemi Covid-19. Prosiding Seminar Official Statistics 2020: Pemodelan Statistika tentang Covid-19. Politeknik Statistika STIS. Diakses dari https://prosiding.stis.ac.id/index.php/semnasoffstat/article/download/516/94/

BPS. (2021a). Berita Resmi Statistik: Profil Kemiskinan di Indonesia September 2020. Jakarta: Badan Pusat Statistik. Diakses dari https://www.bps.go.id/pressrelease/2021/02/15/1851/persentase-pendudukmiskin-september-2020-naik-menjadi-10-19-persen.html

BPS. (2021b). Pendapatan Nasional Indonesia 2016-2020. Jakarta: Badan Pusat Statistik

BPS. (2021c). Produk Domestik Regional Bruto Provinsi-Provinsi di Indonesia Menurut Lapangan Usaha 2016-2020. Jakarta: Badan Pusat Statistik

BPS. (2021d). Statistik Nilai Tukar Petani 2020. Jakarta: Badan Pusat Statistik

Edwards, Mary E. (2007). Regional and Urban Economics and Economic Development. Auerbach Publications

IMF. (2021). World Economy Outlook 2021. Washington, DC: International Monetary Fund

Mellor, John W. (2017). Agricultural Development and Economic Transformation. Palgrave Macmillan 
Octania, Galuh. (2020, Agustus). Agriculture Resilient to Pandemic's Impact. The Jakarta Post. Diakses dari https://www.thejakartapost.com/news/2020/08/08/agriculture-resilient-to-pandemics-impact.html

Simatupang, P. dan Isdijoso, B. (1992). Pengaruh Pertumbuhan Ekonomi terhadap Nilai Tukar Sektor Pertanian: Landasan Teori dan Bukti Empiris. Ekonomi dan Keuangan Indonesia Vol. 40 No. 1. Diakses dari https://www.lpem.org/repec/lpe/efijn1/199203.pdf

Soepono, Prasetyo. (1993). Analisis Shift Share: Perkembangan dan Penerapan. Jurnal Ekonomi dan Bisnis Indonesia Vol. 8 Tahun 1993. Diakses dari https://journal.ugm.ac.id/jieb/article/view/40049/22565

Stimson, R. J., Stough, R.R., dan Roberts, B.H. (2006). Regional Economic Development: Analysis and Planning Strategy $\left(2^{\text {nd }}\right.$ ed). Springer

Sudarmono, M. (2006). Analisis Transformasi Struktural, Pertumbuhan Ekonomi Dan Ketimpangan Antar Daerah di Wilayah Pembangunan I Jateng, (Tesis Pasca Sarjana, Universitas Diponegoro, 2006). Diakses dari http://eprints.undip.ac.id/15738/

World Bank. (2021). Global Economic Prospect. Washington, DC: World Bank

World Bank. (2008). World Development Report 2008: Agriculture for Development. Washington, DC: World Bank

\section{LAMPIRAN}

Hasil Pengelompokan Prioritas Pembangunan Subsektor Tanaman Pangan pada 34 Provinsi di Indonesia

\begin{tabular}{|c|c|c|c|c|c|c|c|}
\hline \multirow{2}{*}{ Provinsi } & \multicolumn{2}{|c|}{$\begin{array}{c}\text { Analisis Location } \\
\text { Quotient }\end{array}$} & \multicolumn{4}{|c|}{ Analisis Shift Share } & \multirow{2}{*}{ Kelompok } \\
\hline & Nilai LQ & Kat. LQ & Nilai $M_{i j}$ & Kat. $\mathrm{M}_{\mathrm{ij}}$ & Nilai $C_{i j}$ & Kat. $C_{i j}$ & \\
\hline (1) & $(2)$ & (3) & (4) & (5) & (6) & (7) & (8) \\
\hline Aceh & 1,78 & $>1$ & 37227,96 & $>0$ & $-16125,48$ & $<0$ & Prioritas 2 \\
\hline Sumatera Utara & 1,28 & $>1$ & 108099,09 & $>0$ & $-73222,20$ & $<0$ & Prioritas 2 \\
\hline Sumatera Barat & 2,09 & $>1$ & 56223,42 & $>0$ & $-33974,58$ & $<0$ & Prioritas 2 \\
\hline Riau & 0,30 & $<1$ & 23511,51 & $>0$ & 7920,99 & $>0$ & Prioritas 2 \\
\hline Jambi & 0,67 & $<1$ & 15769,71 & $>0$ & $-1714,71$ & $<0$ & Alternatif \\
\hline Sumatera Selatan & 0,96 & $<1$ & 48178,68 & $>0$ & $-38817,76$ & $<0$ & Alternatif \\
\hline Bengkulu & 2,77 & $>1$ & 20375,52 & $>0$ & $-16634,56$ & $<0$ & Prioritas 2 \\
\hline Lampung & 3,34 & $>1$ & 127476,03 & $>0$ & 23404,69 & $>0$ & Prioritas 1 \\
\hline $\begin{array}{l}\text { Kep. Bangka } \\
\text { Belitung }\end{array}$ & 0,23 & $<1$ & 1907,40 & $>0$ & 5644,00 & $>0$ & Prioritas 2 \\
\hline Kep. Riau & 0,00 & $<1$ & 72,93 & $>0$ & $-219,31$ & $<0$ & Alternatif \\
\hline DKI Jakarta & 0,00 & $<1$ & 157,08 & $>0$ & 834,12 & $>0$ & Prioritas 2 \\
\hline Jawa Barat & 1,11 & $>1$ & 257353,14 & $>0$ & 2293,70 & $>0$ & Prioritas 1 \\
\hline Jawa Tengah & 1,42 & $>1$ & 217763,37 & $>0$ & $-93548,97$ & $<0$ & Prioritas 2 \\
\hline DIY & 1,12 & $>1$ & 18120,30 & $>0$ & 20413,60 & $>0$ & Prioritas 1 \\
\hline Jawa Timur & 1,07 & $>1$ & 274155,09 & $>0$ & $-123149,88$ & $<0$ & Prioritas 2 \\
\hline Banten & 0,72 & $<1$ & 50613,42 & $>0$ & 11457,94 & $>0$ & Prioritas 2 \\
\hline Bali & 0,62 & $<1$ & 14428,92 & $>0$ & $-16666,56$ & $<0$ & Alternatif \\
\hline NTB & 3,56 & $>1$ & 52745,22 & $>0$ & $-49172,46$ & $<0$ & Prioritas 2 \\
\hline NTT & 2,58 & $>1$ & 28207,08 & $>0$ & $-40626,24$ & $<0$ & Prioritas 2 \\
\hline Kalimantan Barat & 1,12 & $>1$ & 23842,50 & $>0$ & $-40077,50$ & $<0$ & Prioritas 2 \\
\hline Kalimantan Tengah & 0,57 & $<1$ & 9015,27 & $>0$ & $-7472,55$ & $<0$ & Alternatif \\
\hline Kalimantan Selatan & 1,49 & $>1$ & 31034,52 & $>0$ & $-42043,20$ & $<0$ & Prioritas 2 \\
\hline Kalimantan Timur & 0,08 & $<1$ & 5705,37 & $>0$ & 1657,71 & $>0$ & Prioritas 2 \\
\hline Kalimantan Utara & 0,15 & $<1$ & 1452,99 & $>0$ & 4094,79 & $>0$ & Prioritas 2 \\
\hline Sulawesi Utara & 1,00 & $>1$ & 14041,83 & $>0$ & $-21675,98$ & $<0$ & Prioritas 2 \\
\hline Sulawesi Tengah & 1,06 & $>1$ & 22529,76 & $>0$ & $-12730,72$ & $<0$ & Prioritas 2 \\
\hline Sulawesi Selatan & 2,26 & $>1$ & 117568,77 & $>0$ & $-75026,06$ & $<0$ & Prioritas 2 \\
\hline Sulawesi Tenggara & 0,66 & $<1$ & 9839,94 & $>0$ & $-7998,24$ & $<0$ & Alternatif \\
\hline Gorontalo & 6,73 & $>1$ & 30333,27 & $>0$ & $-39362,96$ & $<0$ & Prioritas 2 \\
\hline Sulawesi Barat & 1,98 & $>1$ & 10081,17 & $>0$ & 5355,06 & $>0$ & Prioritas 1 \\
\hline Maluku & 2,03 & $>1$ & 9912,87 & $>0$ & $-4735,56$ & $<0$ & Prioritas 2 \\
\hline Maluku Utara & 0,56 & $<1$ & 2462,79 & $>0$ & $-1453,09$ & $<0$ & Alternatif \\
\hline Papua Barat & 0,08 & $<1$ & 757,35 & $>0$ & $\begin{array}{l}-577,80 \\
\end{array}$ & $<0$ & Alternatif \\
\hline Papua & 0,88 & $<1$ & 19214,25 & $>0$ & $-17159,25$ & $<0$ & Alternatif \\
\hline
\end{tabular}

